\title{
The Relation between Recreational Education and Social Responsibility at Secondary School in Dakahleya Governorate
}

\section{*Dr/ Mohammed Elsayad Elsayad Mattar \\ *** Dr/ Hazem Mohammed Yousef Mansour}

\section{Research Summary}

The researchers have carried out this study in order to analyze the relationship between recreational education and social responsibility at Dakahleya Governorate secondary schools. The researchers used descriptive method, recreational education scale and social responsibility scale (from a recreational perspective), developed by researchers to collect data. The study has been applied to a sample of (209) Physical education teachers and supervisors and (1172) secondary school students for main experiment and (50) physical education teachers and supervisors for exploratory experiment. The most important results were the awareness of most secondary school students of the concept and objectives of participation in recreation education areas. Recreational education instills in students the sense of social participation, and increases their sense or responsibility towards society and the attempt to revive and develop it. A direct statistically significant relationship had been detected between recreational education and social responsibility for secondary school students in Dakahleya Governorate.

\section{Introduction and Research Problem: \\ Modern scientific} advancement has become the landmark of this age, for its fast development, new attitudes and modern ideas that affect its approach and system. This development provides many opportunities to know all that is new in all fields of life.

Lecturer at Sport Recreation Department, Faculty of Physical Education, Mansoura University.

" Lecturer at Sport Recreation Department, Faculty of Physical Education, Mansoura University. 
Sammanudy et. al points out that recreational activities are a part of educational process. Through participation in multiple and various activities, students acquire many skills (whether kinetic, mental or social) necessary to correctly invest spare time, which helps achieve physical, psychic, mental and social balance for students (Sammanudy et. al. :2014).

The absence of a sense of responsibility is a negative feeling that has great effects on the community. This is exemplified by the behavior of some students in schools, where these behaviors lack in commitment, responsibility, preservation of public property, the spirit of loyalty and belonging, and are characterized by the disintegration of social relations both among students each other and between students, teachers and supervisors. A clear manifestation of students' lack of a sense of responsibility is misuse of toilets and electric appliances, damaging them and failure to maintain the overall shape of the school, as some students put stickers or write their names and draw pictures and shapes on walls and seats, which distort the overall view. The lack of a sense of responsibility is also reflected by the use by some students of means of cheating in exams, recklessness, waste of time, indifference, lack of selfconfidence, laziness, mutual reliance, inaction to participate in public service camps and lack of participation in voluntary activities to serve the school and the surrounding community.

This is in line with Ramadan's study, which confirms that some students have some negative behavioral aspects, such as lack of punctuality, mutual reliance, lack of belonging, opportunism, lack of responsibility and failure to preserve the institution's property (Ramadan: 2015).

Ismail confirms that social responsibility makes students important and influential components in their groups, in particular, and in society in general. It also engages students' interest in social affairs and the problems facing society, and makes them keen on participating in solving these problems. Moreover, it makes students depend on 
themselves, as self-dependent students shall be responsible for their actions, having a sense of belonging to their community (Ismail: 2011).

Social responsibility is one of the most important social qualities that can only be developed through practice and recreational education as an area dealing with students through which social responsibility can be developed. (Sammanudy et al.: 2014), (Mahrous :2012), (Tahany : 2001) point out that the area of recreational education helps promote independence, self-confidence, self-reliance and social responsibility by letting students choose and plan activities. Moreover, it develops citizenship and loyalty through the work of organizations that require collective efforts, such as sports teams and community social service. In addition, it provides an opportunity for social participation and social service, which benefits students by introducing them to their society; its principles, ethics and duties and respect for community rules and laws. This being important, secondary school students increasingly need to have social responsibility so as to achieve a balance between intellectual and social activities, which encouraged the two researchers to study the relationship between recreational education and social responsibility for secondary school students (from a recreational perspective)

\section{Need and Significance:}

1. Although recreational education is important in educational process and in forming and developing the personality of students through participation in recreational activities which develop their skills and instill good values in them, there is, to the knowledge of the two researchers, no study to define the relation between recreational education and social responsibility for secondary school students.

2. This study will be of great use for those interested in student activities and in recreational education areas and their effect on modifying students' attitudes and behaviors and changing them to the better.

3. It will help those in charge renew scholastic discourse in general and 
recreational activities in particular through some activities that aim at developing the sense of belonging and social participation.

4. It is a subsidiary means of planning for preparing students to take on their social roles in order to participant in building society.

5. The study will contribute to enriching arab studies and research in social and educational sciences.

Objective:

The study aims at defining the relation between recreational education and social responsibility at high schools in Dakahleya Governorate through answering the following questions:

1. What is the concept and objectives of recreational education?

2. What are recreational education areas and obstacles?

3. What is ethical responsibility and social participation responsibility (from a recreational perspective)?

4. What is citizenship responsibility, loyalty and legal responsibility (from a recreational perspective)?
5. What is the correlation relationship between recreational education and social responsibility for secondary school students in Dakahleya Governorate?

\section{Procedures:}

The researchers have applied the descriptive survey method.

\section{Population and Sampling:}

\section{Study}

population consists of physical education students and teachers at Dakahleya Governorate secondary schools in academic year (2014-2015). Researchers have randomly chosen the sample, which consisted of (209) of physical education teachers and supervisors, (1172) secondary school students in Dakahleya Governorate for basic sample and (50) physical education teachers and supervisors for exploratory sample and from outside basic sample.

\section{Data Collection Tool:}

Sport recreational education measure which consisted of (56) items distributed among (4) dimensions, set up by researchers, and social responsibility measure (from a historic perspective) which consisted of (63) items 
distributed among (4) dimensions, set up by researchers, to define the relationship between recreational education and social responsibility at Dakahleya Governorate secondary schools.

Field Study:

Having been satisfied with validity and reliability coefficients, researchers have applied recreational education and social responsibility (from a recreational perspective) scales at Dakahleya Governorate secondary schools to main study sample which consisted of (209) physical education teachers and supervisors and

secondary school students from (1/10/2014 to 31/12/2014). Scales having been applied, data has been entered in order to carry out proper statistical treatments.

\section{Design Stages of Recreational} and Social Responsibility Scales (From a Recreational Perspective) at Dakahleya Governorate Secondary Schools:

Through theoretical readings, reference studies and survey of opinions of (7) experts in recreation and psychology (Appendix A), the researchers have developed recreational education and social responsibility scales (from a recreational perspective) with the aim to define the relationship between recreational education and social responsibility at Dakahleya Governorate secondary schools. Recreational education scale consisted of (4) dimensions. These were: recreational education concept, objectives, areas and obstacles. Social responsibility (from a recreational perspective) scale consisted of (4) dimensions. These were: ethical responsibility, social participation responsibility, citizenship and belonging responsibility and legal responsibility.

The initial design of recreational education and social responsibility (from a recreational perspective) scales have been presented to experts to make sure dimensions are suitable for the analysis of the relationship between recreational education and social responsibility. Dimensions for each scale have been established (Appendices $\mathrm{B}$ and $\mathrm{C})$. 
In light of relative weight of derived dimensions, (59) items of recreational education scale and (69) items of social responsibility (from a recreational perspective) scale have been distributed to experts to make sure the items were suitable to define the relationship between recreational education and social responsibility and to give them a linguistic formula. (56) Items of recreational education scale and (63) items of social responsibility (from a recreational perspective) scale have been established after presenting them to experts and conducting internal consistency check, Appendices (D) and (E). A score for each dimension alone has been set and a total score according to a three-point scale (Yes $=3$ points - To a Certain Extent $=2$ points $\mathrm{NO}=1$ point).

Total score for scale was then calculated. Scientific coefficients of recreational education scale and social responsibility (from a recreational perspective) scale were calculated at Dakahleya Governorate secondary schools.

Review and Discussion of Results:

\section{Frequencies and} Percentiles of Recreational Education Concept

Table (6) shows the order of recreational education concept according to teachers' and supervisors' opinions (an area for achieving total and balanced education for students participating in it during spare time) by $(83.09 \%)$. Yet, the items which have gained highest score according to students' opinions are (meaningful activities practiced during leisure time and in which students voluntarily participate and which are conductive to personal happiness) by $(84.07 \%)$. This may be due to the fact that different recreational education areas are constructive activities in which students voluntarily participate. Moreover, it contributes to the development and advancement of their personality and helps them acquire many mental, physical, heath, social and psychic experiences and achieve balance and integration in their public and academic life. In addition, participation in recreational activities help students achieves the happiness they seek. This is in line with what (Sammanudy et al. :2014) 
and (Garrett :2013) have pointed out.

2. Frequencies

and

Percentiles of Recreational Education Objectives

Table (7) shows the order of recreational education objectives according to teachers' and supervisors' opinions (renewing bodily activity and vitality) by $(86.76 \%)$, while the item that gained highest score according to students' opinions is (acquiring new instructional and educational experiences) by $(84.21 \%)$. This may be due to the fact that motive for movement and activity is considered important for all students in this age group, that sport activities are the most loved activities by students, and that it is important to renew bodily activity and restore its vitality through participating in different recreational education activities at school so that students can go on their academic life, carry on their work, proceed with their burdens and required assignments. This is in line with what both (Al Hamahemy, 'Aydah: 2006) and (Tahany: 2001) have pointed out: that there are a number of objectives and aims which students seek to achieve.

\section{Frequencies and} Percentiles for Recreational Education Areas

Table (8) shows the order of recreational education areas according to teachers' and supervisors' opinions (team games: football - volleyball handball - basketball) by $(85.80 \%)$, while the item that achieved highest score was recreational trips by $(83.76 \%)$. This may be due to the fact that the motive for movement and activity is an important one for all students in this age group and that sport group activities are most loved by most students. Moreover, trips are favorite activities for students, for the opportunity they provide for escape, movement, entertainment and change to academic life style. This is in line with studies by (Mahrous: 2012) and (Shalaqamy: 2010), which point out that sport games and recreational trips are activities which automatically interest most students.

4. Frequencies and Percentiles of Recreational Education Obstacles

Table (9) shows the order of recreational education 
obstacles according to teacher's and supervisors' opinions (lack of awareness of the concept and importance of participating in recreational activities) by $(86.12 \%)$, while the item which achieved highest score according to student's opinions is not letting students participate in the planning and choice of recreational activities by $(84.10 \%)$. This may be due to lack of interest by many students at this stage in practicing recreational activities and the focus on academic achievement. Most schools, as well, do not take into consideration student participation and do not ask for students' opinions when developing and planning school year plan for recreational education activities and areas. This is in keeping with studies by (Shalaqamy: 2010) and (Othman: 2003) as to the lack in recreational culture and the lack of awareness of how important recreational activities are for students.

5. Frequencies

and

Percentiles of Ethical Responsibility

Table (10) shows that the item that achieved highest score according to teachers' opinions was (to abide by the ethics, conventions and traditions of society) by (86.60\%), and that highest item in score in students' opinion is (I make sure my actions are right and my behaviors are correct) by ( $86.66 \%)$. This may be due to the importance of recreational education and its role in instilling more sublime ethics in students, as it helps them adapt to the surrounding environment and teaches them the art of ethical dealing with others and how to behave properly in different situations. Therefore, it protects and enables them to avoid various behavior deviations. This is in line with studies by (Mahrous: 2003) and (Kharashy: 2004): Towards contribution by recreational activities to development of good ethics, good treatment and good behavior for students.

\section{Frequencies and}

Percentiles of Social

Participation Responsibility

Table (11) shows that highest item in score according to teachers' and students' opinions is (I care to be a useful and productive member of society) by $(86.76 \%)$ and $(83.02 \%)$. This is due to the role played by 
recreational education areas in developing students and their sense of responsibility towards society, encouraging them to positively participate in its revival, development and advance it forward, as they are the men of the future and focusing their attention on giving society more than taking from it. This is in line with studies by (Sammanudy et al.:2015) and (Suleiman: 2008) which point out that participation in recreational activities has an effect on developing social responsibility for students.

7. Frequencies and Percentiles of Citizenship And Loyalty

Table (12) shows the order of items according to teachers and students. (I feel proud of the history and civilization of my country) comes first by $(86.44 \%)$ and $(83.56 \%)$. This is due to the interest in having recreational areas and activities that promote the value of society and its civilized history throughout ancient and modern history to students, through introducing them to historical events and evidence for the country in all political, scientific, artistic and sport areas. This is consistent with studies by (Sammanudy et al. :2015) and (Mahrous: 2012) on the importance of recreational education in acquiring social responsibility and developing desired attitudes.

\section{Frequencies and Percentiles of Legal Responsibility}

Table (13) shows the order of items according to teachers, and that (I feel that I am responsible for the revival and development of my society as a member thereof) has a score of $(86.28 \%)$. The highest item in score according to students is (I take responsibility and accept liability when practicing activities) by ( $83.90 \%)$. This is due to the fact that recreational education is considered a rich area with opportunities to develop self-confidence for students, the ability to take responsibility and the characteristics of leadership dependency and cooperation with clients. This is in line with studies by (Sammanudy et al.:2015) and (Mahrous: 2012) which point out that there is a positive attitude by students practicing activities recreational towards 
responsibility for oneself, others and society.

Table (1)

Coefficients of correlation between recreational education dimensions and scale as a whole and social responsibility

dimensions and scale as a whole, according to students (1172=n)

\begin{tabular}{c|c|c|c|c|c|c|c|c|c|c|c}
\hline \hline Axis & Concept & Objectives & Areas & Obstacles & $\begin{array}{c}\text { Scale } \\
\text { Total } \\
\text { Score }\end{array}$ & $\begin{array}{c}\text { Ethical } \\
\text { Responsibility }\end{array}$ & $\begin{array}{c}\text { Social } \\
\text { Participation }\end{array}$ & $\begin{array}{c}\text { Citizenship } \\
\text { and } \\
\text { Loyalty }\end{array}$ & $\begin{array}{c}\text { Social } \\
\text { Legal } \\
\text { Responsibility } \\
\text { Scale Total } \\
\text { Score }\end{array}$ \\
\hline \hline Concept & & $* 0.995$ & $* 0.346$ & $* 0.889$ & $* 0.355$ & $* 0.363$ & $* 0.267$ & $* 0.375$ & $* 0.249$ & $* 0.236$ \\
\hline Objectives & & & $* 0.740$ & $* 0.370$ & $* 0.500$ & $* 0.057$ & $* 0.817$ & $* 0.726$ & $* 0.659$ & $* 0.404$ \\
\hline Areas & & & & $* 0.123$ & $* 0.661$ & $* 0.223$ & $* 0.248$ & $* 0.998$ & $* 0.197$ & $* 0.107$ \\
\hline Obstacles & & & & & $* 0.453$ & $* 0.087$ & $* 0.676$ & $* 0.071$ & $* 0.553$ & $* 0.791$ \\
\hline $\begin{array}{c}\text { Scale Total } \\
\text { Scores }\end{array}$ & & & & & $* 0.186$ & $* 0.141$ & $* 0.332$ & $* 0.255$ & $* 0.556$ \\
\hline \hline
\end{tabular}

Table $\mathrm{R}$ value at $(0.05)$ significance level $=(0.052)$

Table (1) shows the statistically significant direct correlational relationship between recreational education dimensions and social responsibility dimensions according to students, as the $\mathrm{R}$ value is calculated to be higher than its table value at $(0.05)$ significance level. This is due to the fact that recreational education greatly contributes to providing opportunities for students to achieve social, psychic, physical and mental development as well as instills values required for students and familiarizes them with duties and rights, which leads to achieving the most sublime aim and objective: good citizenship. This is in keeping with studies by (Sammanudy et al. :2015) and (Mahrous :2012) as to the important role played by recreational education to instill the sense of social participation for students.

\section{Conclusions}

* Most secondary school students have heeded the concept and objectives of participation in recreational education areas.

* Recreational education helps develop ethical aspects, preserve social relationships and abidance by normal behaviors by students.

* Recreational education instills a sense of social participation for students and heightens their sense of responsibility towards society and the need to bring about its revival and development.

* Recreational education contributes to promoting national identity through pride and a feeling of belonging to homeland. 
* There is a statistically significant direct relationship between recreational education and social responsibility for Dakahleya Governorate secondary school students.

Recommendations:

* Ministry of Education need to take an interest in activating school and recreational activities through application of recreational week proposal in schools and incorporating it in school year plan of Ministry. * Social responsibility and ethical values need to be a primary axis when developing recreational education objectives in school activity. Moreover, educational attitudes and contemporary issues must be incorporated into these objectives.

* Students participating in recreational school activities need to be distinguished through recognition and awards in order to give them more motivation to continue participating in recreational activities.

* The number of activity staff and supervisors need to be enough for the numbers of students participating in different recreational activities. * Students need to be directed towards activities suitable to their preferences, trends and abilities so that they practice them voluntarily and feel satisfied.

\section{References:}

1- Ahmad Suleiman (2008): (Relation between Practicing Sport Activities and Social Responsibility for Assiut University students), a master thesis, not published, Faculty of Physical Education, Assiut University.

2- Akram Othman (2003): (Outdoor Recreation Culture for Preparatory School Students and its Relation to Practiced Activities), a master thesis, not published, Faculty of Physical Education for boys, Helwan University.

3- Amro Ramadan (2015):

(Participation in Recreational

Camps and its Relation to Social Responsibility and SelfEsteem for Mansoura University Students), an unpublished master thesis, Faculty of Physical Education, Mansura university, p.p 3.

4- Ayman Shalaqamy (2010): (Egyptian School Camps and their Role in Practice of Recreational Activity by Students), a master thesis, Faculty of Physical Education for boys, Helwan University.
5 - Mohammed Al Hamahemy' aydah Abdel 
Aziz (2006): (The Theory and Practice of Recreation), 3rd edition, Cairo, Alkitab Publishing House, p.p91.

6- Mohammed Ismail (2011): (Academic Cheating as a Dormant Behavior and ITS Relation to Studying Skills and Social Responsibility for Faculty of Physical Education Students in Mansura and Damietta), an unpublished master thesis, Faculty of Physical Education, Mansoura University, p.p 52.

7- Mohammed Mahrous (2012): (The Relation between Recreational Education and School Activity at Primary School in Alex Governorate), an unpublished master thesis, Faculty of Physical Education, Alex University.

8- Mohammed Sammanudy et al. (2014): (Sport Recreation pproach), Mansoura, Shajardar Bookshop, p.p 101,102.

9- Mohammed Sammanudy et al. (2014): (Recreational Education), Mansoura, Shajardar Bookshop, p.p 86, 83.

10- Mohammed Sammanudy et al. (2015): (The Relationship between Participating in Recreational Camps and Social Responsibility for University Students), a published research paper, Faculty of Physical
Education

Mansoura University.

Magazine,

11- Smith Garett (2003): Perceptions of an intermodal extracurricular sports program in an urban middle school Dissertation abstract international vol. 64-05 A, p. 1590.

12- Tahany abdel Salam (2001): (Recreation and Recreational Education), Dar Al-Fikr, Cairo, p.p119, 120,115 .

13- Waleed Kharashy (2004): (The Role of Student Activities in developing social Responsibility), a master thesis, King Saud, KSA. 